УДК 631.527.5:633.63:631.527.82

(C) 2012

Парій Ф. М., доктор біологічних наук, Андрошук М. П., аспірант

Уманський національний університет садівництва

Труи С. Г., кандидат сільськогосподарських наук

Інститут коренеплідних культур Національної Академії аграрних наук України

\title{
ПРОДУКТИВНІСТЬ ПРОБНИХ ГІБРИДІВ БУРЯКІВ ЦУКРОВИХ, СТВОРЕНИХ НА ОСНОВІ ПОЛІПШЕНОЇ СТЕРИЛЬНОЇ ФОРМИ ТА БАГАТОРОСТКОВИХ ЗАПИЛЮВАЧІВ РІЗНОГО ПОХОДЖЕННЯ
}

\author{
Рецензент - доктор сільськогосподарських наук, професор А. Ф. Балабак
}

\begin{abstract}
Вивчення батьківських компонентів є важливим напрямом досліджень. Використання в якості материнської форми лінії ЧС 94 дозволяє створювати гетерозисні гібриди з високим рівнем продуктивності. Авторами вивчено вплив поліпшеної за комплексом селекційно-генетичних ознак стерильної лінії на прояв господарськи цінних ознак у створених гібридів цукрових буряків. Проведено випробування отриманих гібридів та оиінено

показники їх продуктивності. Лінію ЧС 94 рекомендовано залучати до селекиійного прочесу з формування високопродуктивних гібридів буряків иукрових нового покоління.
\end{abstract}

Ключові слова: буряк иукровий, гібрид, багаторосткові запилювачі, иитоплазматична чоловіча стерильність, чоловічостерильні форми, стерильна плазма.

Постановка проблеми. На сучасному етапі розвитку гетерозисної селекції буряків цукрових основним завданням досліджень $є$ створення високопродуктивних гібридів на основі цитоплазматичної чоловічої стерильності (ЦЧС). Даної мети можна досягти лише за рахунок створення нових, більш досконалих батьківських компонентів гібридів та доборів найбільш продуктивних їх комбінацій.

Аналіз основних досліджень і публікацій, у яких започатковано розв'язання проблеми. Одним із базових компонентів гетерозисних гібридів буряків цукрових $є$ одноросткові чоловічостерильні (ЧС) форми. Використання ЧС форм дає можливість отримати $100 \%$ гібридне насіння, що характеризується високою продуктивністю, генетичною одноманітністю та одноростковістю. Це $\epsilon$ найбільш ефективний і економічно виправданий метод створення гетерозисних гібридів [2]. Насіння гібридів на ЦЧС основі характеризується високим ступенем однонасінності, що дає змогу в процесі очистки доводити його до високих посівних кондицій за показниками енергії проростання й схожості.

Дослідами доведено, що на продуктивність гібридів досить суттєво впливають генетичнодетерміновані ознаки материнського компонента. Це його комбінаційна здатність, базова продуктивність, роздільноплідність, ступінь стерильності та стійкість до хвороб і стресових умов довкілля [1]. Господарськи цінні ознаки батьківського компонента також успадковуються гібридним потомством [3], основною вимогою до якого є забезпечення високого рівня гетерозису у схрещуваннях із відповідними ЧС формами.

Використання в селекційній роботі ЦЧС форм дає можливість не тільки реалізувати ефект гетерозису і біологічний потенціал рослини, але й отримати насіння, що за більшістю параметрів відповідає вимогам інтенсивної технології вирощування буряків цукрових. Добір батьківських компонентів із високими показниками комбінаційної здатності сприяс використанню ефекту гетерозису на кінцевому етапі схрещування [2].

Мета досліджень та методика їх проведення. Оскільки ключова роль у формуванні гетерозисних гібридів буряків цукрових належить одноростковим стерильним формам, метою досліджень було отримання виробничо цінних гетерозисних гібридів та вивчення впливу поліпшеної за комплексом селекційно-генетичних ознак стерильної лінії ЧС 94 на прояв господарсько - цінних ознак у створених гібридів. Стерильну лінію ЧС 94 використали в якості материнської форми при отриманні гетерозисних гібридів буряків цукрових. Коренеплоди ЧС лінії та підібраних для схрещування багаторосткових запилювачів висаджували на просторово ізольованих ділянках.

* Науковий керівник - доктор біологічних наук Ф. М. Парій 
Використано п'ять диплоїдних багаторосткових запилювачів різного походження.

Випробування отриманих гібридів проведено трирядковими ділянками, повторність - трикратна, облікова площа ділянки - 10,8 м². Елементи продуктивності оцінювали на фоні групового стандарту, до якого входили три вітчизняні гібриди, рекомендовані для виробництва: Український ЧС 72, Уманський ЧС 97, Весто.

Урожай коренеплодів визначали шляхом зважування їх із кожної ділянки, вміст цукру - методом холодної дигестії на автоматичній технологічній лінії «Венема». Дані продуктивності гібридів опрацьовували статистично методом дисперсійного аналізу, використовуючи пакет програм «Аналіз даних електронних таблиць «Microsoft Exel»»».

Результати досліджень. Аналіз результатів досліджень свідчить, що окремі гібридні комбінації, отримані за участі лінії ЧС 94, мали вищі показники збору цукру з 1 га порівняно із груповим стандартом.

За результатами станційного сортовипробування високим показником збору цукру на фоні групового стандарту характеризувалася комбінація лінії ЧС 94 та запилювача Ум. БЗ 460/08, що становить 116,4 \% від групового стандарту. Ця комбінація також мала кращі відносні показники за врожаєм коренеплодів, відповідно, $114,7 \%$ та цукристістю - 101,2 \% (див. табл.).

Гібрид ЧС 94 х Ум. БЗ 1705/08 забезпечив приріст за результуючим показником продуктивності збором цукру з 1 гектара, що становить 113,6 \% від, урожай коренеплодів - $116,1 \%$, цукристості - 97,6\% від групового стандарту. Підвищена продуктивність гібридів обумовлювалася приро- стом урожаю коренеплодів, а в окремих випадках i цукристості. Наприклад, у гібриду від схрещування лінії ЧС 94 і запилювача Ум. Б3 76/08 урожай коренеплодів, відповідно, становив $108,4 \%$, цукристість - 102,4 \%, збір цукру $111,1 \%$ до групового стандарту.

Комбінація ЧС 94 х Уманський БЗ 33/08 перевищувала груповий стандарт за врожаєм коренеплодів на 5,6 \%, за цукристістю - на $3 \%$, за збором цукру - на $9 \%$.

Характеризуючи гібридну комбінацію із запилювачем Ум. Льв. оп. 399/08, слід відмітити, що за врожаєм коренеплодів вона була на рівні групового стандарту, за цукристістю перевищила груповий стандарт на $2,4 \%$, а за збором цукру на $3,1 \%$.

Порівняльний аналіз результатів досліджень свідчить, що за врожаєм коренеплодів два гібриди, створені на основі лінії ЧС 94, достовірно перевищили груповий стандарт. Про високу продуктивність отриманих гібридів свідчить також приріст за показником «вихід цукру з 1 гектара». Використання в якості материнської форми лінії ЧС 94 сприяло підвищенню врожаю коренеплодів пробних гібридів, а також збору цукру з одиниці площі.

Висновки. За результатами досліджень, викладених у статті, можна зробити наступні висновки: 1. Отримані експериментальні дані свідчать, що використання в якості материнської форми лінії ЧС 94 дає змогу створювати гетерозисні гібриди з високим рівнем продуктивності.

2. Лінію ЧС 94 рекомендовано залучати до селекційного процесу з формування високопродуктивних гібридів цукрових буряків нового покоління.

Показники продуктивності пробних гібридів цукрових буряків (2007-2010)

\begin{tabular}{|c|c|c|c|c|c|c|c|}
\hline \multirow{2}{*}{$\begin{array}{l}\text { № } \\
\Pi / \Pi\end{array}$} & \multirow{2}{*}{$\begin{array}{l}\text { Комбінації } \\
\text { схрещувань }\end{array}$} & \multirow{2}{*}{$\begin{array}{c}\text { Урожай ко- } \\
\text { ренеплодів, } \\
\text { т/га }\end{array}$} & \multirow{2}{*}{$\begin{array}{l}\text { Цукрис- } \\
\text { тість, \% }\end{array}$} & \multirow{2}{*}{$\begin{array}{c}\text { 3бір } \\
\text { цукру, } \\
\text { т/га }\end{array}$} & \multicolumn{3}{|c|}{$\begin{array}{c}\text { Оцінки показників продуктивності, } \\
\text { \% до стандарту }\end{array}$} \\
\hline & & & & & $\begin{array}{c}\text { урожай } \\
\text { коренеплодів }\end{array}$ & $\begin{array}{l}\text { цукрис- } \\
\text { тість }\end{array}$ & $\begin{array}{l}\text { збір } \\
\text { цукру }\end{array}$ \\
\hline 1 & $\begin{array}{c}\text { ЧС } 94 \mathrm{x} \\
\text { Ум. Б3 } 460 / 08\end{array}$ & 32,7 & 17,0 & 5,56 & 114,7 & 101,2 & 116,4 \\
\hline 2 & $\begin{array}{c}\text { ЧС } 94 \mathrm{x} \\
\text { Ум. Б3 } 1705 / 08 \\
\end{array}$ & 33,1 & 16,4 & 5,43 & 116,1 & 97,6 & 113,6 \\
\hline 3 & $\begin{array}{c}\text { ЧС } 94 \mathrm{x} \\
\text { Ум. Б3 76/08 } \\
\end{array}$ & 30,9 & 17,2 & 5,31 & 108,4 & 102,4 & 111,1 \\
\hline 4 & $\begin{array}{c}\text { ЧС } 94 \mathrm{x} \\
\text { Ум. Б3 33/08 } \\
\end{array}$ & 30,1 & 17,3 & 5,21 & 105,6 & 103,0 & 109,0 \\
\hline 5 & $\begin{array}{c}\text { ЧС } 94 \text { х } \\
\text { Ум. Льв. оп. } 399 / 08 \\
\end{array}$ & 28,2 & 17,2 & 4,03 & 99,0 & 102,4 & 103,1 \\
\hline \multicolumn{2}{|r|}{ Груповий стандарт } & 28,5 & 16,8 & 4,78 & 100,0 & 100,0 & 100,0 \\
\hline & $\mathrm{HIP}_{0,5}$ & 3,41 & 0,69 & 0,61 & - & - & - \\
\hline
\end{tabular}




\section{БІБЛІОГРАФІЯ}

1. Вакуленко П. І. Продуктивність гібридів цукрових буряків на стерильній основі залежно від структури материнського компонента: Автореф. дис. ... канд. с.-Г. наук. - К., 2007. - 20 с.

2. Сливченко А. М., Кулік О. Г., Сливченко О. А. Селекція закріплювачів стерильності // Цукрові буряки, 2003. - №. - С. 6-7.
3. Труш С. Г., Рябовол Л. О., Баланюк Л. О., Татарчук В. М. Оцінка базисної продуктивності і комбінаційної здатності багатонасінних запилювачів цукрових буряків // Збірник наукових праць Уманського державного аграрного університету. - Умань: УДАУ, 2007. - Вип. 64. - Ч. 1. C. 71-78. 